\title{
Remote sensing depicts riparian vegetation responses to water stress in a humid Atlantic region
}

\author{
G. Pace ${ }^{\mathrm{a}, \mathrm{b}, *}$, C. Gutiérrez-Cánovas ${ }^{\mathrm{a}, \mathrm{b}}$, R. Henriques ${ }^{\mathrm{c}}$, F. Boeing ${ }^{\mathrm{d}}$, F. Cássio ${ }^{\mathrm{a}, \mathrm{b}}$, C. Pascoal $^{\mathrm{a}, \mathrm{b}}$ \\ a Centre of Molecular and Environmental Biology (CBMA), Department of Biology, University of Minho, Campus of Gualtar, 4710-057 Braga, Portugal \\ ${ }^{\mathrm{b}}$ Institute of Science and Innovation for Bio-Sustainability (IB-S), University of Minho, Campus of Gualtar, 4710-057 Braga, Portugal \\ c Department of Earth Sciences, University of Minho, Institute of Earth Sciences (ICT), Campus of Gualtar, 4710-057 Braga, Portugal \\ d Department of Computational Hydrosystems, Helmholtz Centre for Environmental Research (UFZ), Leipzig, Germany
}

\section{H I G H L I G H T S}

- We modelled NDVI productivity of riparian plants from Sentinel 2 images.

- Inter-annual seasonality differed between drier and wetter years.

- Broadleaved, coniferous and grasslands forests were intercompared.

- NDVI productivity was influenced by annual rainfall and vegetation type.

\section{A R T I C L E I N F O}

\section{Article history:}

Received 26 October 2020

Received in revised form 26 January 2021

Accepted 26 January 2021

Available online 1 February 2021

Editor: Christian Herrera

\section{Keywords:}

NDVI

Primary productivity

Forestry

Sentinel 2

Climate change

Rivers
G R A P H I C A L A B S T R A C T
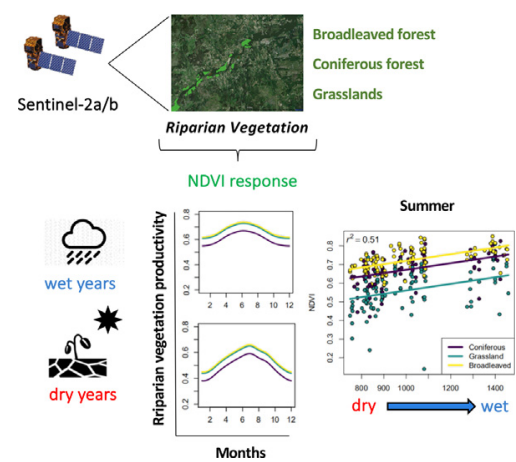

\begin{abstract}
A B S T R A C T
Riparian areas in the Cantabrian Atlantic ecoregion (northwest Portugal) play a key role in soil formation and conservation, regulation of nutrient and water cycle, creation of landscape aesthetic value and the preservation of biodiversity. The maintenance of their ecological integrity is crucial given the ever increase in multiple anthropogenic (water demand and agriculture) and climatic pressures (droughts and extreme events). We developed a transferable remote sensing approach, taking advantage of the latest freely available technologies (Sentinel-2 and Copernicus Land products), to detect intra-annual and inter-annual changes in riparian vegetation productivity at the river basin scale related to water stress. This study has used the normalized difference vegetation index (NDVI) to investigate riparian vegetation productivity dynamics on three different vegetation types (coniferous, broadleaved and grassland) over the past 5 years (2015-2019). Our results indicated that inter-annual seasonality differed between drier (2017) and wetter (2016) years. We found that intra-annual dynamics of NDVI were influenced by the longitudinal river zonation. Our model ranked first $\left(r^{2} \mathrm{~m}=0.73\right)$ showed that the productivity of riparian vegetation during the dry season was positively influenced by annual rainfall and by the type of riparian vegetation. The emergent long lags between climatic variation and riparian plant productivity provides opportunities to forecast early warnings of climatically-driven impacts. In addition, the different average productivity levels among vegetation types should be considered when assessing climatic impacts on riparian vegetation. Future applications of Sentinel 2 products could seek to distinguish riparian areas that are likely to be more vulnerable to changes in the annual water balance from those that are more resistant under longer-term changes in climate.
\end{abstract}

(C) 2021 Elsevier B.V. All rights reserved.

\footnotetext{
* Corresponding author at: Centre of Molecular and Environmental Biology (CBMA), Department of Biology, University of Minho, Campus of Gualtar, 4710-057 Braga, Portugal. E-mail address: giorgio.pace@bio.uminho.pt (G. Pace).
} 


\section{Introduction}

Riparian zones represent transitional areas occurring between land and freshwater ecosystems, that provide many ecosystem functions and services related to water quality, microclimate regulation, structural habitat for wildlife, energy base for the food web, and bank stability (Naiman et al., 2005). Particularly, riparian plants represent a primary energy source for in-stream consumers, especially in headwater sections, having a strong influence on the structure of freshwater communities (e.g. macroinvertebrate shredders; Ono et al., 2020). Moreover, the composition and structure of riparian vegetation can affect the suitability of habitat for riparian predators as well as the terrestrial stages of aquatic organisms (Larsen et al., 2015). Riparian vegetation provides shade and regulates microclimate conditions, which can influence the activity and dispersal patterns of several adult aquatic insects (e.g. Ephemeroptera, Plecoptera and Trichoptera) and amphibians (Collier and Smith, 2000; Briers et al., 2003; Kominoski and Rosemond, 2012). In addition, riparian vegetation can capture and filter surface runoff due to physical impact of living and dead plants on hydraulics, mitigating impacts of sedimentation or nutrients on aquatic ecosystems (Dosskey et al., 2010). However, riparian ecosystems are exposed to multiple anthropogenic pressures, such as agriculture, climate change or hydromorphological alterations, which deteriorate their health (Bruno et al., 2016; Stella and Bendix, 2019) and may trigger cascading environmental effects and long-term consequences related to water quality, flow moderation, soil erosion and biodiversity conservation (Swanson et al., 2017).

Climate change is expected to cause shifts in precipitation and stream runoff patterns, including extreme differences between high and low streamflow, reduce groundwater recharge, alter nutrient dynamics and ecosystem functions (Johnson et al., 2012; Raymondi et al., 2013). Drought is one of the most dramatic consequences of climate change with impacts on the biosphere. Although drought events are common in arid or semi-arid and Mediterranean climate regions, with documented impacts on freshwater ecosystems (e.g. Bond et al., 2008), these events are intensifying across the globe even in humid and temperate regions (Gómez-Gener et al., 2020; Masante et al., 2018). This may be the case of northwest Portugal, located in a transition between Mediterranean and Atlantic climate, where mean annual rainfall can be greater than 2500 mm (Trigo and Da Camara, 2000). Indeed, in this region, a strong reduction in mean precipitation and duration of the rainy season is expected to occur according to climate change scenarios (IPCC, 2014; Miranda et al., 2002; Nunes et al., 2019).

These changes in climate may lead to significant alterations in several physiological aspects and phenophases of riparian plants, such as, leaf unfolding and flowering of plants in spring or colour changing and leaf fall in autumn (Gordo and Sanz, 2010). The effects of changing climate have been also associated with a considerable increase in the susceptibility of riparian plant species to pathogens and insect pests, leading to regional tree die-offs (Breshears et al., 2005) and changes in the distribution of vegetation (Bodner and Robles, 2017). Moreover, physiological performance of plant responses to climate stress may vary between different plant species and tissues (Garssen et al., 2014; Sun et al., 2020). For example, willows (Salix sp.) are considered more sensitive to drought than cottonwoods (Populus sp.), due to their smaller seed size and a slower growth of roots (Amlin and Rood, 2002). In addition, gradual climate change may lead to long-term destabilisation of grassland and forest communities, favoring forest species with slower phanerophyte dynamics (Barros et al., 2018).

Since some changes may occur gradually and others may occur episodically (e.g., wildfire), long-term monitoring is needed to detect accurately where, when, and how climatic effects occur for riparian vegetation (Dwire et al., 2018) and to better discern the influences of interannual climatic variability from management, disturbance, or other human activities (Albano et al., 2020). However, due to the spatial arrangement, dynamism and inaccessibility of riparian ecosystems, collecting data in field studies can be difficult and labour-intensive, especially for large areas (i.e. at the river basin scale or for more than $100 \mathrm{~km}$ of a river) (Johansen et al., 2007).

Remote sensing techniques have been recognized as a convenient way to obtain continuous data, over a variety of scales and resolutions, and have been recently used for studying fluvial environments, especially the riparian zones (Tomsett and Leyland, 2019). Traditionally, the Land Satellite (Landsat) Thematic Mapper (TM), the French Systeme Pour L'Observation de la Terre (SPOT) and the Advanced Spaceborne Thermal Emission and Reflection Radiometer (ASTER) have proven effective for mapping wide riparian buffers, land cover, and changes in large coastal watersheds (Goetz, 2006; Klemas, 2014). Recent advances in techniques and satellite programs have generated an increased availability of very high-resolution data that will help to better assess links between riparian vegetation main traits (e.g., biomass productivity, phenology) and climatic variability and extremes. Among the freeavailable satellite programs, the polar-orbiting Landsat-8 (launched 2013), Sentinel-2A (launched 2015) and Sentinel-2B (launched 2017) sensors offer high resolution satellite images ( $10 \mathrm{~m}$ to $30 \mathrm{~m}$ ) multispectral global coverage providing images of the Earth's entire surface every few days (Li and Roy, 2017; Sudmanns et al., 2019). This increased frequency of image acquisition together with the advances in the ability to process data provides new opportunities for detecting rapid or gradual riparian vegetation changes. For instance, these techniques allow for a better characterization of riparian vegetation properties (e.g., diversity, biomass, health) and dynamics (e.g., phenology and phenophases) than it was previously possible (Goetz, 2006). When using remote sensing, vegetation phenology is typically monitored by means of time series of spectral vegetation indices that provide a rapid and non-destructive method to estimate the fraction of photosynthetically active radiation absorbed by Earth's vegetation (Novillo et al., 2019). Among the high number of vegetation indices, the Normalized Difference Vegetation Index (NDVI) has been frequently used to assess long-term trends of vegetation (Peng et al., 2012), to monitor system primary productivity over time (Stöckli and Vidale, 2004) and, more recently, to investigate productivity-diversity relationship (Wang et al., 2016; Rocchini et al., 2018; Torresani et al., 2019). In addition, NDVI anomaly has been correlated to pant growth reduction, loss of green coverage and eventual tree mortality in response to environmental change (Camarero et al., 2015; Lloret et al., 2016; Breshears et al., 2005; Rajah et al., 2019; Gouveia et al., 2017; Senf et al., 2020). Focusing more specifically on remote-sensed studies that investigated relationships between riparian vegetation health and climatic variability and extremes, a linear relationship between NDVI and antecedent rainfall periods has been documented in arid to semi-arid regions, where high temperature and water stress are common (Wang et al., 2003; Fu and Burgher, 2015; Birtwistle et al., 2016; Albano et al., 2020). In contrast, less documented are NDVI responses to climate variability, in humid and temperate regions, where water stress is an emerging threat (Gómez-Gener et al., 2020; Masante et al., 2018). In addition, previous studies have suggested that the major climatic factors affecting NDVI response may vary among climatic regions, riparian vegetation structure and management type (Huntington et al., 2016; Fesenmyer et al., 2018).

In this study, we developed a transferable remote sensing approach aiming to i) detect intra-annual and inter-annual changes in riparian vegetation productivity at the river basin scale related to water stress, ii) assess how climatic variability (rainfall) and catchment attributes (elevation, vegetation type and management) influence the riparian vegetation productivity during the dry season. We employed temporal analysis (from 2015 to 2019) based on the long-term Normalized Difference Vegetation Index (NDVI) data sets derived from Sentinel-2 sensors in order to detect changes in the long-term vegetation productivity of riparian zones. We expect that decreased precipitation will increase water stress and induce loss of NDVI-based primary productivity on riparian plants. Specifically, we hypothesize that: (i) Increasing water stress inhibit plant growth and photosynthesis, influencing the duration 
of vegetation greenness across seasons, with detectable intra-annual changes in NDVI; (ii) productivity of riparian zone during the dry season increases when more precipitation is accumulated over long periods of time, i.e. the higher the precipitation along the year, the higher the water storage and the NDVI; and (iii) water stress responses differ among riparian tree forest with higher stability of forests than grasslands due to the slower phanerophyte dynamics (they grow slower, live longer and mature later).

\section{Materials and methods}

\subsection{Case Study: Cávado River basin}

All study sites are at the Cávado River basin in the north Portugal (Fig. 1). This basin occupies an area of $1589 \mathrm{~km}^{2}$, with a mean elevation of $564 \mathrm{~m}$ with several peaks of $1500 \mathrm{~m}$, and an average population density of ca. 200 inhabitants $/ \mathrm{km}^{2}$ (minimum of 22 at Montalegre and maximum of 1770 at Braga) (Vieira et al., 1998). The annual average precipitation is
$2348 \mathrm{~mm}, 42 \%$ of which is concentrated in the months of December, January and February. Mean annual air temperatures is $12.7^{\circ} \mathrm{C}$, with a maximum average temperatures of $16.2^{\circ} \mathrm{C}$ and a minimum average of $8.3{ }^{\circ} \mathrm{C}$ (Portal do Clima http://portaldoclima.pt/en/, Trigo and Da Camara, 2000). The water is intensively used for hydropower generation, domestic and industrial water supply and agricultural irrigation. Main tributaries are the Rabagão River (left side, with a drainage area of $257 \mathrm{Km}^{2}$ ) and the Homem River (right side, with a drainage area of $246 \mathrm{~km}^{2}$ ). According to the conceptual geobotanical proposals of RivasMartínez et al. (2017), the Cávado river basin cross two different biogeographic region of the Iberian Peninsula: primarily, the Cantabrian Atlantic Subprovince and to the smallest extent, the Atlantic Orolusitanian Subprovince. We focused our study on the distribution of the three mayor riparian vegetation types of the Cantabrian Atlantic landscape (Amigo et al., 2017): coniferous forest, broadleaved forests and grasslands. These forests play a key role in soil formation and conservation, the regulation of nutrient cycle and the water cycle, the production of various goods and services (e.g. firewood, timber and wild mushrooms),

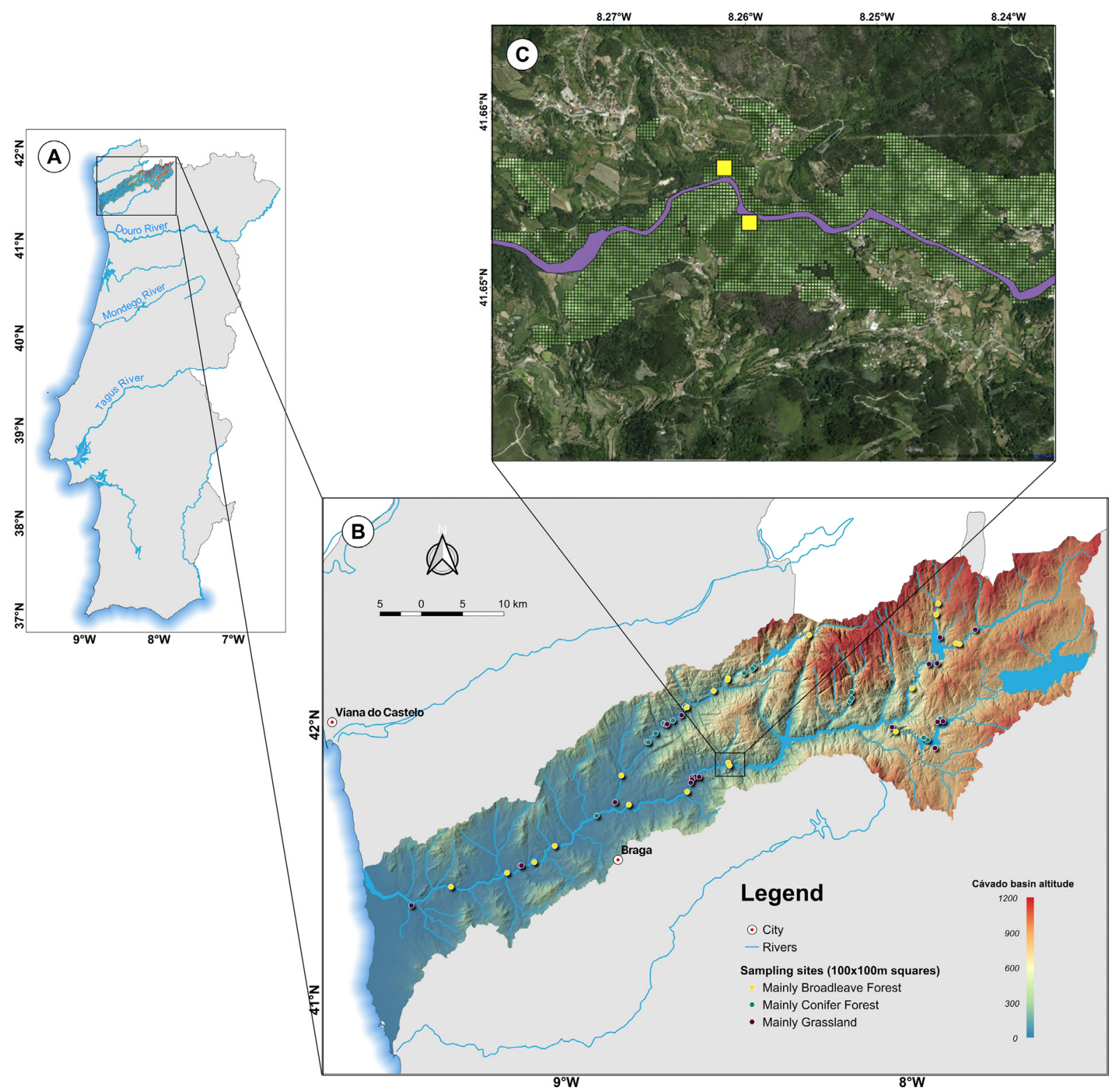

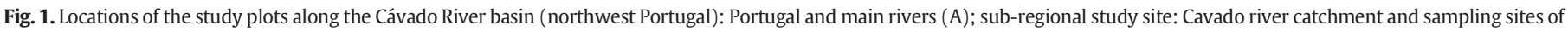

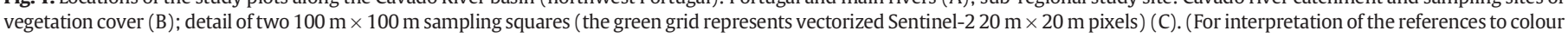
in this figure legend, the reader is referred to the web version of this article.) 
the creation of aesthetic and landscape value (mostly associated with forest and agrosystem mosaics) and the preservation of biodiversity. Particularly, coniferous forests are dominated by presence of Pinus pinaster. Native broadleaved forests are dominated by presence of Quercus robur and Quercus pyrenaica followed by Alnus glutinosa, Salix atrocinerea, Laurus nobilis and Crataegus monogyna, that characterize the GalicioPortuguese oak woods (Habitat 9230 sensu Habitats Directive, European Commission, 1992; European Commission, 2013); A. glutinosa, Fraxinus excelsior, Osmunda regalis and S. atrocinerea, that characterize the Alluvial forests Osmundo-Alnion (Habitat 91E0 sensu Habitats Directive, European Commission, 1992; European Commission, 2013). However, broadleaved forests also include Eucalyptus globulus, since the native forests in Northern Spain and Northern Portugal have been replaced gradually and widely by Eucalyptus plantations. Perennial Grasslands are dominated by the presence of Arrenatherum elatius that characterize the Molinio-Arrhenatheretea association (Habitat 6510 sensu Habitats Directive, European Commission, 1992; European Commission, 2013), and of wet meadow species (Lotus pedunculatus, Juncus acutiflorus, Cyperus longus, Cardamine pratensis) that characterize the Cynosurion association (Habitat 6410 sensu Habitats Directive, European Commission, 1992; European Commission, 2013).

\subsection{Materials}

\subsubsection{Copernicus land monitoring service: Riparian Zone}

The Riparian Zone (RZ) is a local Copernicus Land Monitoring Service (CLMS - https://land.copernicus.eu/local/riparian-zones) Open Access product that supports the objectives of many European legislations, such as the Birds and Habitats Directives (European Commission, 1992; European Commission, 2009), the Water Framework Directive (European Commission, 2000) and the Floods Directive (European Commission, 2007). RZ consists of three products: Delineation of Riparian Zone (DRZ), Land Cover/Land Use (RZ LC/LU) and Green Linear Elements (GLE). Particularly RZ LC/LU provides very detailed information of the riparian environment (LC/LU classes and its characteristics) along large and medium sized rivers (Piedelobo et al., 2019).

We used RZ LC/LU to derive the distribution of Coniferous forest, Grasslands and Broadleaved forest within our study area.

\subsubsection{Sentinel-2 multispectral imagery}

The presented work used Sentinel-2 satellite data (S2A MSI L1C), since it offers freely available high spatial resolution images $(10 \mathrm{~m}$ to $20 \mathrm{~m}$ ) and multi-spectral global coverage with high temporal resolution.

We selected 1 scene (T29TNG tile) per month for the period of July 2015 (Sentinel-2A was lunched on 23 June 2015) to December 2019, with the lowest amount of noise (e.g., shadows and clouds). Therefore, scenes having a cloud cover higher than $15 \%$, including those with partial presence of noise within the study areas (e.g. upper part of the basin comparing to the lower), were discarded to avoid misinterpretation of the results. Particularly, the high temporal resolution (10 days using one satellite, 5 days using two) offered by Sentinel-2 products, allow us to have more chance to achieve completely cloud-free scenes. This resulted in 43 valid observations (date of Sentinel-2 images used are reported in Table S2), acquired from the EarthExplorer (EE) user interface (https://earthexplorer.usgs.gov/) developed by United States Geological Survey (USGS).

\subsubsection{Ancillary data}

Since there are few long-term weather stations within our study area and where available the data series provided is largely incomplete (https://snirh.apambiente.pt), we used gridded $5 \mathrm{~km}$ temperature and precipitation dataset (2015-2019) implemented within the CLIMALERT project (www.climalert.eu). The underlying station data set is the global surface summary of day (GSOD v7, https://www.ncei.noaa.gov/data/ global-summary-of-the-day). Spatial fields have been generated using external drift kriging with elevation as additional information. In Table S1 we resume the main characteristics of input products and data used in the proposed methodology.

\subsection{Methodology}

The proposed steps deliver a transferable remote sensing approach (Fig. 2) based on Open Access data to detect intra-annual and interannual changes in riparian vegetation productivity at the river basin scale related to water stress.

\subsubsection{Pre-processing}

To assure that the main input RZ LC/LU were suitably characterizing the riparian areas in the case study area, they were cross-checked with Google Earth satellite's high-resolution images, loaded in QGIS via the QuickMapServices plugin. Successively, twenty plots $(100 \times 100 \mathrm{~m})$ were placed within each riparian vegetation class following a sampling design similar to other studies (Rocchini et al., 2016; Rocchini et al., 2018; Torresani et al., 2019). In this way, we assure a better fit (up-scaling) among the higher spatial resolution of Sentinel data and the coarser resolution of RZ LU/LC and climatic data used, without losing information in terms of correlation between spectral variability and species diversity (Rocchini et al., 2010; Schmidtlein and Fassnacht, 2017). In addition, to avoid mixed pixel (water-vegetation), that could lead to data misinterpretation (over representation in NDVI means), study plots were cross-checked and validated based on intersection of study plots with river network and evaluating the influence of the canopy and the river width in doubtful cases with Google Earth satellite's high-resolution images.

Based on MAES concept (Mapping \& Assessment of Ecosystems and their Services) and using the Level 2 and 3 of Hierarchical Nomenclature associated with the RZ LC/LU layer, information on management type were derived characterizing each study plots into natural/semi-natural or cultivated/managed areas. Specifically, in natural areas, the vegetative cover is in balance with the abiotic and biotic forces of its biotope; in semi-natural areas, vegetation is defined as not planted by humans but influenced by human actions (e.g., grazing); whereas in cultivated and managed areas, vegetation is considered artificial and requires human activities to maintain it in the long term (Di Gregorio, 2005).

Digital Surface Models (DSM's) were also used, to derive altitude values for each study plots. In addition, to assess if river longitudinal zonation influence NDVI-based primary productivity, study plots were grouped into three river sections (upper, middle and lower), taking into account their spatial proximity.

Concerning satellite data, all 43 images were pre-processed for atmospheric correction, using Dark Object Substract 1 (DOS1) correction carried out with the Semi-Automatic Classification plugin (Congedo, 2016) in QGIS.

Concerning precipitation data, we firstly extract monthly data of the covered period using QGIS. Successively, for each year, we calculated several cumulative rainfall metrics for different periods by summing up month input data: May-July (rain spring); February-April (rain winter); November-January (rain autumn). Annual rainfall amounts (rain_12m) were computed, starting from 1 month before the beginning of the dry periods (August), as determined below. This onemonth lead was introduced in order to take into account the lag between photosynthetic activity variations and those of rainfall (adapted from Camberlin et al., 2007).

All the analyses were performed in QGIS 3.10.12 (Quantum GIS Development Team, 2009).

\subsubsection{Processing and outputs}

2.3.2.1. Calculation and multitemporal analysis of phenological variable (NDVI). Following atmospheric correction, NDVI was calculated for all 43 images as per Eq. (1) using bands 4 and 8 in Sentinel- 2 which have 


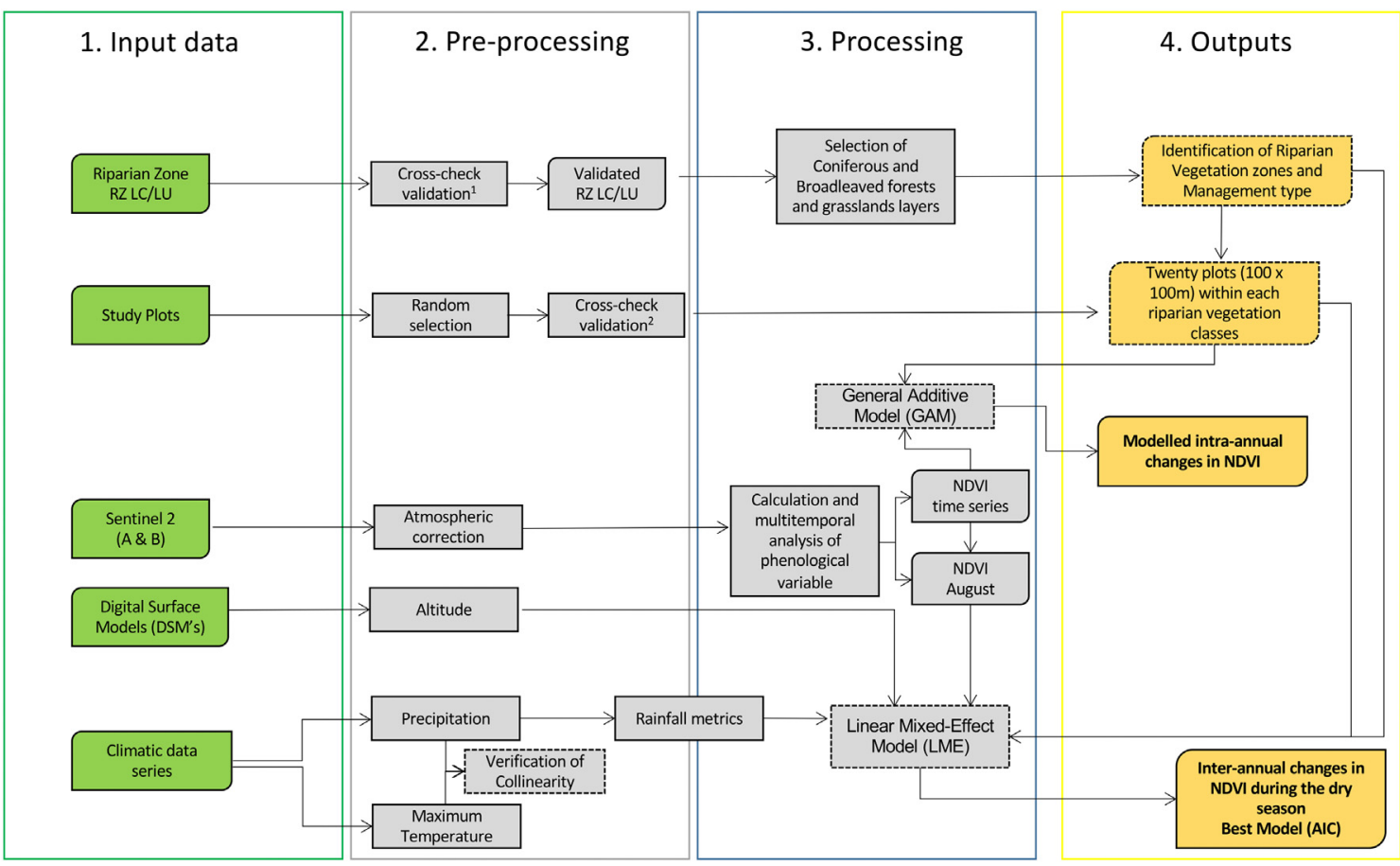

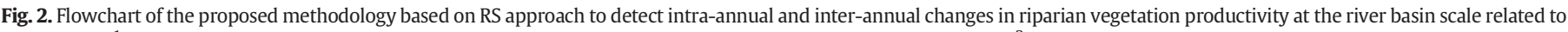

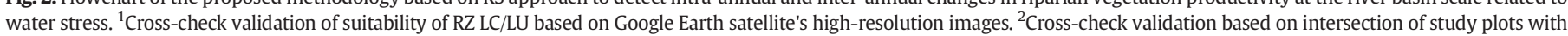
river network and inspection with Google Earth satellite's high-resolution images.

been calibrated to sense radiation in the visible (Red) and near-infrared (NIR) regions of the spectrum respectively.

$N D V I=(N I R-R e d) /(N I R+R e d)$

NDVI values range between -1.0 and 1.0 with values nearing zero and below indicating features which are not vegetated such as water, snow, ice, clouds and barren surfaces. Next, using the derived NDVI rasters (at $10 \mathrm{~m}$ pixel size), for each plot we extracted the average NDVI values within the plot area $(100 \times 100 \mathrm{~m}$ in our case) representing our NDVI value in respect to the local riparian vegetation class.

2.3.2.2. Modelled intra-annual and inter-annual changes in NDVI. Firstly, to estimate intra-annual and inter-annual variation in overall riparian vegetation productivity (NDVI), we used General Additive Models (GAM) based on monthly data averaged by spatial group ( $\mathrm{n}=132$ ), accounting the 3 major riparian vegetation types (grasslands, conifer, broadleaved) of our case study region.

GAMs included year, month and spatial group data and an interaction between month and year as predictors. Month was smoothed using a cubic spline $(\mathrm{k}=12)$ to capture seasonal variation. We tested the inclusion of the interaction and the appropriateness of GAM respect to a linear model with the same set of predictors using Akaike Information Criterion (AICc) for small samples. To conduct GAMs, we used the mgcv R library (Wood, 2017).

Secondly, we used linear mixed-effect models (LME) and a multimodel inference approach (Burnham and Anderson, 2002) to explore if inter-annual changes in NDVI during the dry season were explained by catchment aspects, riparian vegetation type and/or climate. We focused on August NDVI values because it is the month of maximum hydrologic stress over the hydrological year (Trigo and Da Camara, 2000).

We first built nine LME, including (as fixed factors): exclusively catchment features (altitude, riparian vegetation type and management type), exclusively climatic predictors (with different rainfall metrics), or a combination of them, including also interactions between climate and riparian vegetation type (Table 1 ). Interactions allow testing if climate have similar effects across riparian land-uses. Plot was included as random factor to account for multiple measures taken at the same site. To avoid collinearity, we excluded maximum temperature from climatic predictors as it was highly correlated with rainfall variables (Pearson $r>|0.70|)$. Second, based on AICc, we ranked the nine alternative models according to their AICc values and retain those with a difference

Table 1

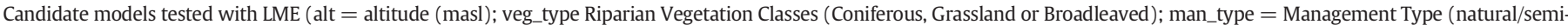

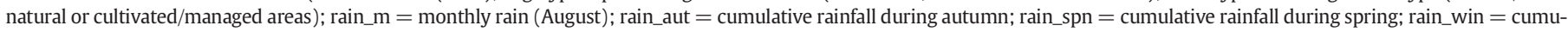
lative rainfall during winter; rain_m:veg_type = Interaction among monthly rain and veg type; rain_12m:veg_type = Interaction among year rain and veg type).

\begin{tabular}{|c|c|c|}
\hline Type of model & Model & Candidate models \\
\hline \multirow[t]{2}{*}{ Exclusively catchment (river basin attributes) } & Model 1 & alt+veg_type,+man_type \\
\hline & Model 2 & rain_m \\
\hline \multirow[t]{4}{*}{ Exclusively climatic (rainfall metrics) } & Model 3 & rain_12m \\
\hline & Model 4 & rain_aut + rain_spn +rain_win \\
\hline & Model 5 & alt + lveg_type, + man_type + rain_m \\
\hline & Model 6 & alt + lveg_type,+man_type +rain_m+rain_m:veg_type \\
\hline \multirow[t]{3}{*}{ Mixed (climatic + catchment) } & Model 7 & alt +lveg_type, + man_type +rain_12m \\
\hline & Model 8 & alt +veg_type,+man_typee +rain_m +rain_12m:lveg_type \\
\hline & Model 9 & alt +veg_type,+man_type +rain_aut +rain_spn +rain_win \\
\hline
\end{tabular}


of AICc $\leq 2$ respect to the model showing the model ranking first (Burnham and Anderson, 2002). We also derived total model explained variance $\left(r^{2}\right)$ and Akaike weights $(w)$ for each model to inform on the explanatory capacity and the relative likelihood of each model, respectively. For each LME model, two measures of goodness-of-fit were estimated (Nakagawa and Schielzeth, 2013): marginal goodness-of-fit $\left(r^{2} \mathrm{~m}\right)$ indicates the variance explained only by the fixed factors, while conditional goodness-of-fit $\left(r^{2} \mathrm{c}\right)$ shows the variance accounted for by both fixed and random terms. In all cases, model residuals were visually assessed to verify linear model assumptions (Zuur et al., 2009).

For final GAM and LME models, we also checked the spatial autocorrelation structure of the models' residuals using Moran's Index (Moran's I) based on each site's coordinates. When the Moran's I values were significantly higher than $I>|0.50|$, we added a residual spatial autocorrelation covariate (RAC) as predictor to capture the spatial effects nonconsidered by the fixed factors (Crase et al., 2012). This RAC term considers the correlation between the residuals at a given plot and those from its neighbouring locations. For final GAM and LME models, we found a temporal dependence in the model residual. In these cases, we added an autoregressive integrated moving average (ARIMA) term to account for the lack of temporal independence of residuals.

\section{Results}

\subsection{Inter-annual and intra-annual climatic and riparian vegetation NDVI patterns}

Concerning climatic patterns, 2016 was the wettest year of the series, with a total of $1400 \mathrm{~mm}$ of rainfall, whereas the 2017 was the driest with a total of $800 \mathrm{~mm}$ (Fig. 3a). The highest average temperature was recorded during 2018, followed by 2016 and 2017 (Fig. 3b). In contrast, cooler mean temperatures were found during 2015 and 2019 (Fig. 3b). Inter-annual variability of NDVI values, derived from Sentinel 2, is shown in Fig. 3c. Overall, NDVI values were lower during the driest year (2017) compared to the other years of the analysed temporal series. Outputs from the GAMs for modelled intra-annual changes in NDVI are shown in Fig. 4. Year, month, spatial group and the interaction between month and year were significant predictors of NDVI dynamics (details in Table S3). When looking at intra-annual patterns, NDVI values were generally higher in the middle and lower section of the basin compared to the upper section. Intra-annual dynamics showed marked variations across years, but they all showed maximum NDVI from March to September (Fig. 4); NDVI started to decrease during autumn and showed minimum values during winter. However, the studied seasonal dynamics differed inter-annually. The seasonal maximum NDVI occurred in summer 2016 (NDVI $=0.73 \pm 0.09$ ), whereas minimum occurred in winter 2017 (NDVI $=0.40 \pm 0.14$ ). In 2018, high values of NDVI were maintained until November and then decreased in December. A similar seasonal behaviour was found in 2016. In contrast, in 2017 NDVI started decreasing earlier in August.

\subsection{Catchment and climate influence on NDVI during the dry season}

Model ranked first included both climatic (12 month precipitation) and catchment variables (riparian vegetation types and elevation), but no interactions between them (Model $7 ; \Delta \mathrm{AICc}<2 ; \mathrm{r}^{2} \mathrm{~m}=0.73$; Table 2). Model ranking also suggests that 12 month precipitation is a better predictor of NDVI than seasonal precipitation. Our model ranking also shows that interactions between climatic and catchment variables had low support. Exclusively climatic models tended to explain lower amounts of NDVI variance $\left(\mathrm{r}^{2} \mathrm{c}=4-11 \%\right)$ than exclusively catchment models $\left(r^{2} \mathrm{c}=39 \%\right.$ ), while those including both types of variables had the most explanatory capacity. Precipitation, either annual or seasonal, tended to have a positive influence on NDVI.

When accounting for spatial autocorrelation in the model ranking first (Table 3), 12 month precipitation and vegetation type were still significant and explained $51 \%$ of the variance (Fig. 5 ). In this model, annual rainfall amounts (12 month precipitation) had a significant positive relationship with NDVI, although NDVI showed different levels for each vegetation type. Broadleaved vegetation type tends to have highest NDVI, conifers were linked to higher NDVI than grasslands. However, same effect (slope) across vegetation types was detected (Table 3; Fig. 5). Altitude and management type (natural/seminatural or cultivated/managed areas) were not significantly related to NDVI. Through the end of the dry season, NDVI values were consistently highest for broadleaved forest, intermediate for coniferous and lowest for grassland (Fig. 5).

\section{Discussion}

Our results clearly showed that NDVI-based primary productivity has observable and quantifiable seasonality as revealed by Sentinel 2 satellite remote sensing. Marked seasonal changes between spring/ summer and autumn/winter were common to all years with minimum values occurring during autumn/winter, and maximum values occurring during the spring/summer season in all years. However, differences in NDVI curves were detected between the wettest (2016 and 2018) and the driest (2017) years. These patterns suggest that the decrease in water availability may influence the duration of greenness that can be interpreted as a surrogate of the length of the growing season ( $\mathrm{Fu}$ et al., 2014; Badr et al., 2015). Particularly, drought has generally been associated with reduced leaf longevity in deciduous species, depending on the length and severity of the drought (Leuzinger et al., 2005; Estiarte and Peñuelas, 2015). Therefore, NDVI loss can be used as a a

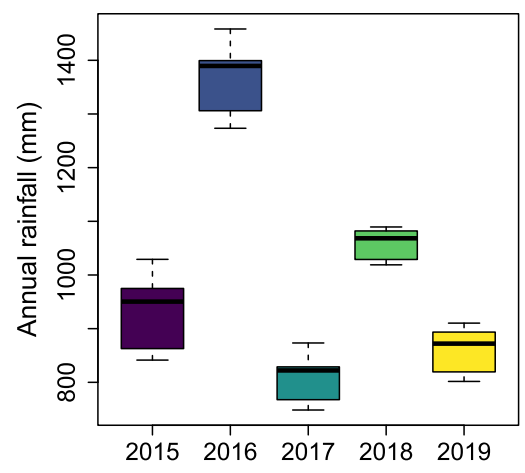

b

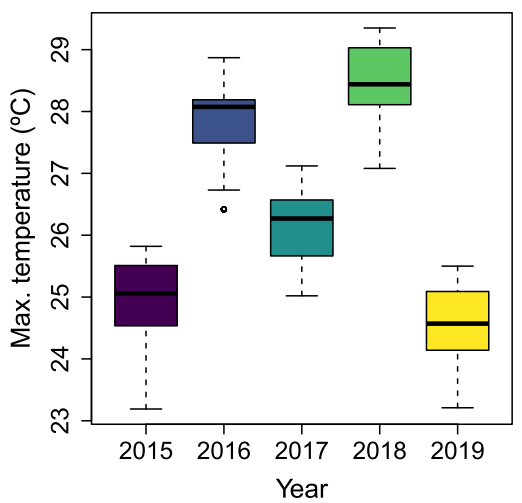

C

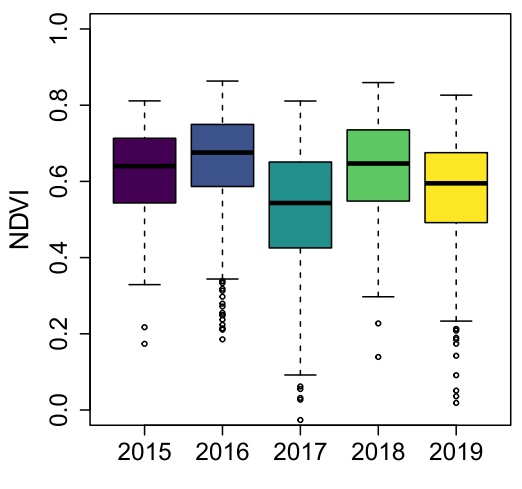

Fig. 3. Interannual variability of annual rainfall (a), maximum average temperature (b) and NDVI (c). 
All period

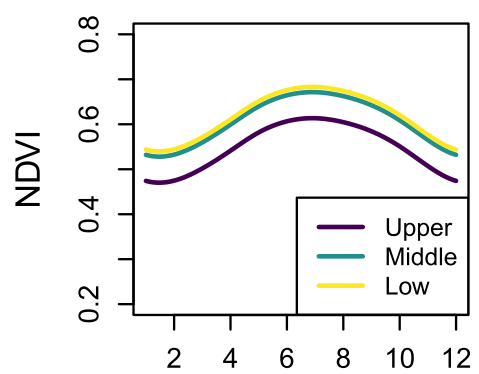

2017

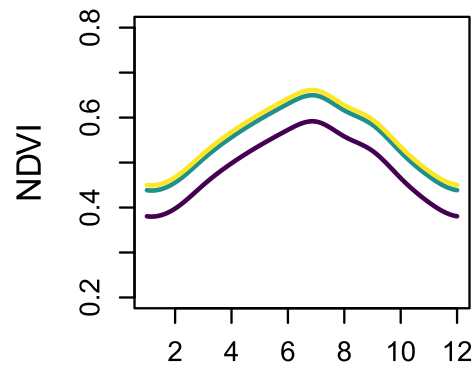

2015

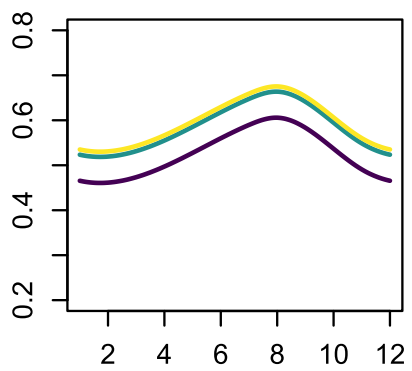

2018

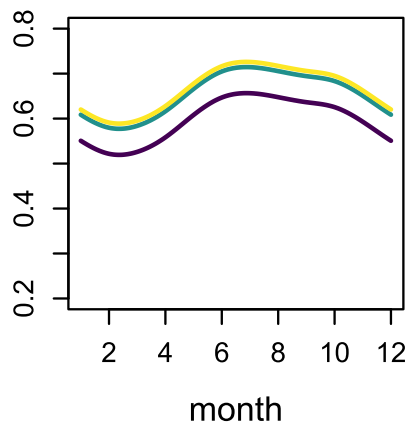

2016

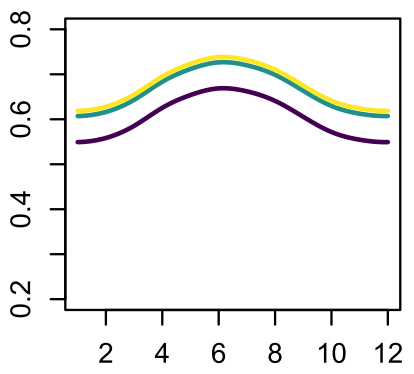

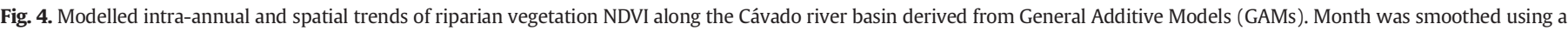
cubic spline $(\mathrm{k}=12)$ to capture seasonal variation.

practical tool to illustrate relevant ecological consequences of water stress on riparian plants, i.e., loss of photosynthetic activity, crown partial dieback, complete or partial foliage drop and reduction leaf longevity.

In our study, NDVI-based primary productivity recovered quickly after the driest year, suggesting high resilience of riparian plants to climate variability. Such high resilience could be explained by the fact that many riparian plants are adapted to hydrologic and climatic disturbances and may tolerate both seasonal and annual variation in environmental conditions (Naiman and Decamps, 1997; Stromberg et al., 2013; Bruno et al., 2016). For example, rapid root extension, reduction in leaf size, crown dieback and branch abscission are common for riparian trees and potentially reduce the stress related to seasonally-variable water content (Stella et al., 2013).

In this study, we found that river longitudinal zonation influence NDVI-based primary productivity with higher NDVI values occurring in the middle and lower sections of the river basin. Such result can be explained considering two aspects: firstly, the commonly observed unimodal pattern of riparian species richness with peaks in the middle reaches of a river (Renöfält et al., 2005; Catford and Jansson, 2014); secondly, the relationship between species richness and productivity (Wang et al., 2016; Torresani et al., 2019). In other words, plots with high riparian species richness may tend to have a higher mean NDVI and lower variation in NDVI than plots with low species richness. Unfortunately, due to the lack of field data such hypothesis needs to be confirmed in further research.

Based on our statistical models, NDVI-based primary productivity during the dry season was positively influenced by annual rainfall for all vegetation types and the response varied slightly among types (broadleaved, coniferous, and grassland). This pattern was not influenced by elevation. Our results also suggest that reductions in annual rainfall severely reduced the productivity of riparian vegetation even in a humid Atlantic climate region. Regional decrease in vegetation productivity (NDVI) in southern Europe was detected during the 2003 drought episode and exhibited important differences between forest types (Gobron et al., 2005; Lobo and Maisongrande, 2005; Lloret et al.,

Table 2

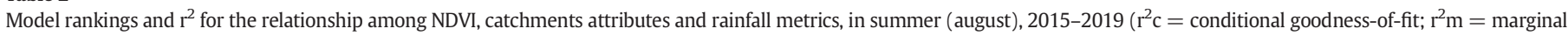

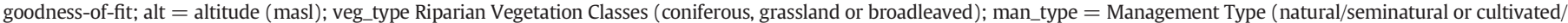

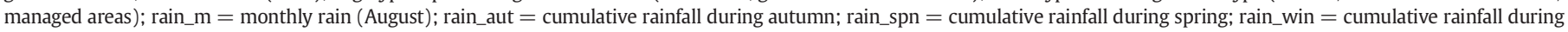
winter; rain_m:veg_type = Interaction among monthly rain and veg type; rain_12m:veg_type = Interaction among year rain and veg type).

\begin{tabular}{|c|c|c|c|c|c|c|c|c|}
\hline Type of model & Candidate models & $r^{2} c$ & $r^{2} m$ & df & logLik & AIC & Delta & Weight \\
\hline Mixed (7) & alt+veg_type,+man_type+rain_12m & 0.50 & 0.73 & 8 & 380.00 & -744.00 & 0.00 & 0.80 \\
\hline Mixed (8) & alt+veg_type,+man_type+rain_12m:veg_type & 0.50 & 0.73 & 10 & 380.55 & -741.10 & 2.90 & 0.19 \\
\hline Mixed (9) & alt+veg_type,e+Rain_aut+rain_spn+rain_win & 0.49 & 0.72 & 10 & 377.24 & -734.48 & 9.52 & 0.01 \\
\hline Exclusively climatic (3) & rain_12m & 0.11 & 0.72 & 4 & 355.11 & -702.22 & 41.78 & 0.00 \\
\hline Exclusively climatic (4) & rain_aut+rain_spn+rain_win & 0.11 & 0.72 & 6 & 352.28 & -692.57 & 51.43 & 0.00 \\
\hline Mixed (6) & alt+veg_type,+man_type+rain_m+rain_m:veg_type & 0.44 & 0.66 & 10 & 352.85 & -685.70 & 58.30 & 0.00 \\
\hline Mixed (5) & alt+veg_type,+man_type+rain_m & 0.43 & 0.65 & 8 & 349.33 & -682.65 & 61.35 & 0.00 \\
\hline Exclusively catchment (1) & alt+veg_type,+man_type & 0.39 & 0.60 & 7 & 333.65 & -653.30 & 90.70 & 0.00 \\
\hline Exclusively climatic (2) & rain_m & 0.04 & 0.65 & 4 & 323.23 & -638.47 & 105.53 & 0.00 \\
\hline
\end{tabular}


Table 3

Significance of fixed effect terms of the best supported model. Significant p-Values are bolded.

\begin{tabular}{|c|c|c|c|c|c|}
\hline & Estimate & Std. error & df & t-Value & p-Value \\
\hline (Intercept) & 0.56141 & 0.02366 & 239 & 23.73 & 0.000 \\
\hline rain_12m & 0.00018 & 0.00002 & 239 & 10.64 & $<0.001$ \\
\hline alt & -0.00003 & 0.00003 & 54 & -1.23 & 0.225 \\
\hline veg_type_typeConiferous & -0.04830 & 0.01896 & 54 & -2.55 & 0.014 \\
\hline veg_type_typeGrassland & -0.15953 & 0.01964 & 54 & -8.12 & $<0.001$ \\
\hline man_type_typenatural/seminatural areas & -0.01855 & 0.01594 & 54 & -1.16 & 0.250 \\
\hline ac & 0.02004 & 0.00775 & 54 & 2.59 & 0.012 \\
\hline
\end{tabular}

2007). Higher anomalies were detected in herbaceous than in woody vegetation, and in deciduous than in evergreen broadleaf forests (Lobo and Maisongrande, 2005). Among coniferous forests, NDVI decreased in Mediterranean (Pinus halepensis) and mesic (Pinus sylvestris) forests, while it did not change significantly in mountain (Pinus uncinata) pine forests (Lloret et al., 2007). According to Barros et al. (2018), drought impacts on structural stability showed that forests were generally more stable than grasslands due to a slower phanerophyte dynamics and because established canopies reduced drought intensity and protected communities from extreme drought effects. However, in contrast to that predicted, we found no differences between forest types and grasslands in terms of responses to the reduction in annual rainfall (Table 3), but differences in the average NDVI levels among vegetation types (broadleaved $>$ conifer $>$ grassland, Fig. 5). These results suggest that changes in riparian vegetation types can severely reduce the productivity of these areas. Considering that riparian zones are the main source of carbon to streams (Lamberti et al., 2017; Ledesma et al., 2018), lower productivity would lead to lower concentration of stream dissolved organic carbon in the catchment (Mzobe et al., 2018) with potential implications to the functioning of these freshwater ecosystems (Warren et al., 2016).

Our results also confirm that variables describing rainfall occurring over shorter periods or seasons had a lower influence on NDVI than accumulated annual rainfall. Moreover, NDVI was significantly correlated with precipitation accumulated during previous periods of the year. Soil water conditions are well known to be one of the foremost drivers of species composition, biomass and plant phenology (Wang et al., 2019). Particularly, soil moisture levels are strongly influenced not only by precipitation accumulated during the current growing season, but also by precipitation accumulated over a relatively long period of

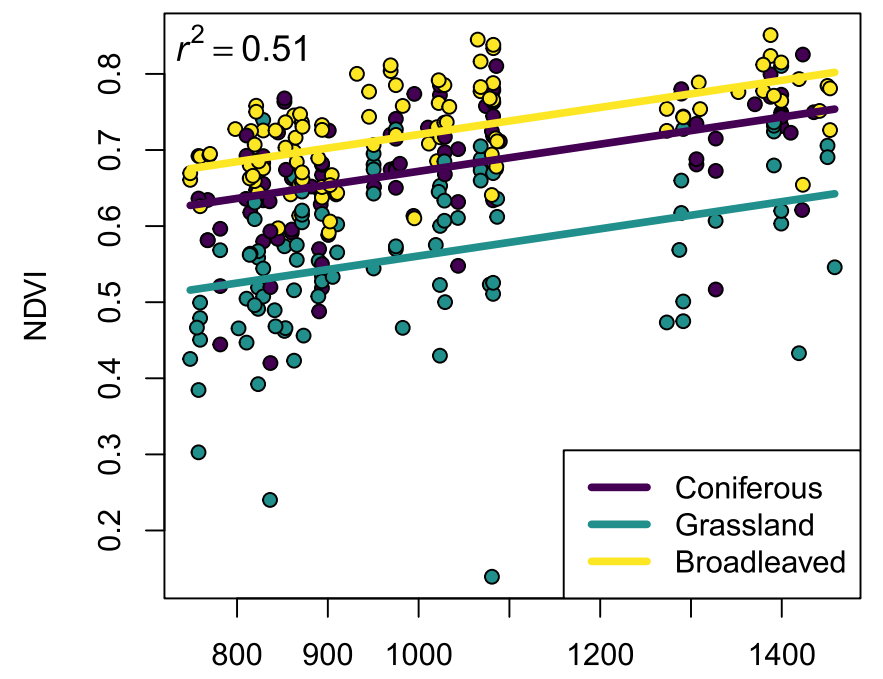

Last 12-month precipitation

Fig. 5. Relationship between NDVI (August) against cumulative precipitation 12 month per Vegetation Type (Coniferous, Grassland, Broadleaved) at the Cávado river basin. time (Wang et al., 2003). Therefore, the more precipitation is stored along the year, the higher NDVI is expected even at the end of the dry season. Indeed, our findings suggest long lags (ca. 1-year time lag) between climatic variation and productivity of riparian vegetation.

\section{Conclusion}

In this study, we demonstrate that Sentinel 2 derived products have the matching temporal and spatial resolution to assess and monitor riparian ecosystem response to water stress, offering an inexpensive and consistent means of simulated time series, that could be updated regularly. The emergent long lags between climatic variation (e.g., annual precipitation) and productivity of riparian vegetation can provide interesting opportunities for forecast NDVI-based primary productivity during the dry season and develop early warnings of productivity anomalies. However, the different average levels of productivity of grasslands, conifer and broadleaved vegetation, depicted in our study, should be considered when assessing climatic impacts on riparian vegetation. Our findings can further help to distinguish those riparian areas that are likely to be more vulnerable to changes in the annual water balance from those that are more resistant under longer-term changes in climate. Although our inferences are limited to our study area, the approach described here are readily transferable to other regions, particularly in understudied or datascarce regions. Finally, this approach, taking advantage of the latest freely available technologies, can support the development of relevant, timely, robust and accessible information that helps policy makers and public users to prioritize management actions for riparian areas and evaluating their effectiveness to improve adaptation to climate change.

\section{CRediT authorship contribution statement}

G. Pace: Conceptualization, Data curation, Formal analysis, Methodology, Writing - original draft, Writing - review \& editing. C. Gutiérrez-Cánovas: Conceptualization, Data curation, Formal analysis, Methodology, Writing - original draft, Writing - review \& editing. R. Henriques: Conceptualization, Data curation, Methodology, Supervision, Writing - original draft, Writing - review \& editing. F. Boeing: Data curation. F. Cássio: Supervision, Writing - review \& editing. C. Pascoal: Conceptualization, Supervision, Writing - original draft, Writing - review \& editing.

\section{Declaration of competing interest}

The authors declare that they have no known competing financial interests or personal relationships that could have appeared to influence the work reported in this paper.

\section{Acknowledgements}

The study was supported by the project CLIMALERT: Climate Alert Smart System for Sustainable Water and Agriculture, an ERA-NET initiated by JPI Climate (ERA4CS programme) co-funded by the EU commission (Grant Agreement 690462) and FCT (ERA4CS/0004/2016). This work was supported by the "Contrato-Programa" UIDB/04050/2020 
funded by national funds through the FCT I.P. (GP). Finally, the authors want to acknowledge the anonymous reviewers for their comments and helpful suggestions.

\section{Appendix A. Supplementary data}

Supplementary data to this article can be found online at https://doi. org/10.1016/j.scitotenv.2021.145526.

\section{References}

Albano, C.M., McGwire, K.C., Hausner, M.B., McEvoy, D.J., Morton, C.G., Huntington, J.L., 2020. Drought sensitivity and trends of riparian vegetation vigor in Nevada, USA (1985-2018). Remote Sens. 12, 1362. https://doi.org/10.3390/rs12091362.

Amigo, J., Rodríguez-Guitián, M.A., Pradinho Honrado, J.J., Alves, P., 2017. The lowlands and midlands of Northwestern Atlantic Iberia. In: Loidi J. (eds) The Vegetation of the Iberian Peninsula. Plant and Vegetation, vol 12Springer, Cham https://doi.org/ 10.1007/978-3-319-54784-8 6.

Amlin, N.M., Rood, S.B., 2002. Comparative tolerances of riparian willows and cottonwoods to water-table decline. Wetlands 22, 338-346. https://doi.org/10.1672/02775212(2002)022[0338:CTORWA]2.0.CO;2.

Badr, G., Hoogenboom, G., Davenport, J., Smithyman, J., 2015. Estimating growing season length using vegetation indices based on remote sensing: a case study for vineyards in Washington State. American Society of Agricultural and Biological Engineers 58, 551-564. https://doi.org/10.13031/trans.58.10845.

Barros, C., Thuiller, W., Munkemuller, T., 2018. Drought effects on the stability of forest grassland ecotones under gradual climate change. PLoS One 13, e0206138. https:// doi.org/10.1371/journal.pone.0206138.

Birtwistle, A.N., Laituri, M., Bledsoe, B., Friedman, J.M., 2016. Using NDVI to measure precipitation in semi-arid landscapes. J. Arid Environ. 131, 15-24. https://doi.org/ 10.1016/j.jaridenv.2015.08.015.

Bodner, G.S., Robles, M.D., 2017. Enduring a decade of drought: patterns and drivers of vegetation change in a semi-arid grassland. J. Arid Environ. 136, 1-14. https://doi. org/10.1016/j.jaridenv.2016.09.002.

Bond, N.R, Lake, P.S., Arthington, A.H., 2008. The impacts of drought on freshwater ecosystems: an Australian perspective. Hydrobiologia 600, 3-16. https://doi.org/10.1007/ s10750-008-9326-z.

Breshears, D.D., Cobb, N.S., Rich, P.M., Price, K.P., Allen, C.D., Balice, R.G., Romme, W.H., Kastens, J.H., Floyd, M.L., Belnap, J., Anderson, J.J., Myers, O.B., Meyer, C.W., 2005. Regional vegetation die-off in response to global-change-type drought. PNAS 102, 15144-15148. https://doi.org/10.1073/pnas.0505734102.

Briers, R.A., Cariss, H.M., Gee, J.H.R., 2003. Flight activity of adult stoneflflies in relation to weather. Ecological Entomology 28, 31-40. https://doi.org/10.1046/j.13652311.2003.00480.x.

Bruno, D., Gutiérrez, Cánovas C., Sánchez-Fernández, D., Velasco, J., Nilsson, C., 2016. Impacts of environmental filters on functional redundancy in riparian vegetation. J. Appl. Ecol. 53, 846-855. https://doi.org/10.1111/1365-2664.12619.

Burnham, K.P., Anderson, D.R., 2002. Model Selection and Multimodel Inference: A Practical Information-Theoretic Approach. 2nd ed. Springer, New York (NY) 978-0-38795364-9 https://doi.org/10.1007/b97636.

Camarero, J.J., Franquesa, M., Sangüesa-Barreda, G., 2015. Timing of drought triggers distinct growth responses in holm oak: implications to predict warming-induced forest defoliation and growth decline. Forests 6, 1576-1597. https://doi.org/10.3390/ f6051576.

Camberlin, P., Martiny, N., Philippon, N., Richard, Y., 2007. Determinants of the interannual relationships between remote sensed photosynthetic activity and rainfall in tropical Africa. Remote Sens. Environ. 106, 199-216. https://doi.org/10.1016/j. rse.2006.08.009.

Catford, J.A., Jansson, R., 2014. Drowned, buried and carried away: effects of plant traits on the distribution of native and alien species in riparian ecosystems. New Phytol. 204, 19-36. https://doi.org/10.1111/nph.12951.

CLIMALERT, 2017. Climate Alert Smart System for Sustainable. Water and Agriculture http://climalert.eu/. (Accessed 12 October 2020).

Collier, K.J., Smith, B.J., 2000. Interactions of adult stoneflflies (Plecoptera) with riparian zones I. Effects of air temperature and humidity on longevity. Aquat. Insects 22, 275-284. https://doi.org/10.1076/0165-0424(200010)22:4;1-Y;FT275.

Congedo, L., 2016. Semi-automatic Classification Plugin for QGIS. Technical Report. Sapienza University, ACC Dar Project, Rome, Italy Available at:. http://fromgistors. blogspot.com.br/p/semi-automatic-classificationplugin.html. (Accessed 10 December 2020).

Crase, B., Liedloff, A.C., Wintle, B.A., 2012. A new method for dealing with residual spatial autocorrelation in species distribution models. Ecography 35, 379-388. https://doi. org/10.1111/j.1600-0587.2011.07138.x.

Di Gregorio, A., 2005. Land Cover Classification System (LCCS): Classification Concepts and User Manual. Software Version (2). Food and Agriculture Organization of the United Nations, Rome 978-92-5-109017-6 2005.

Dosskey, M.G., Vidon, P., Gurwick, N.P., Allan, C.J., Duval, T.P., Lowrance, R., 2010. The role of riparian vegetation in protecting and improving chemical water quality in streams. J. Am. Water Resour. Assoc. 46, 261-277. https://doi.org/10.1111/j.17521688.2010.00419.x.

Dwire, K.A., Mellmann-Brown, S., Gurrieri, J.T., 2018. Potential effects of climate change on riparian areas, wetlands, and groundwater-dependent ecosystems in the Blue
Mountains, Oregon, USA. Climate Services 10, 44-52. https://doi.org/10.1016/j. cliser.2017.10.002.

Estiarte, M., Peñuelas, J., 2015. Alteration of the phenology of leaf senescence and fall in winter deciduous species by climate change: effects on nutrient proficiency. Glob. Chang. Biol. 21, 1005-1017. https://doi.org/10.1111/gcb.12804.

European Commission, 1992. Council Directive 92/43/EEC of 21 May 1992 on the conservation of natural habitats and of wild fauna and flora. Official Journal L 7-50 (22 July 1992).

European Commission, 2000. Directive 2000/60/EC of the European Parliament and of the Council of 23 October 2000 establishing a framework for Community action in the field of water policy. Official Journal L 1-73 (22 December 2000).

European Commission, 2007. Directive 2007/60/EC of the European Parliament and of the Council of 23 October 2007 on the assessment and management of flood risks. Official Journal L 27-34 (6 November 2007).

European Commission, 2009. Directive 2009/147/EC of the European Parliament and of the Council of 30 November 2009 on the conservation of wild birds. Official Journal L 7-25 (26 January 2010).

European Commission, 2013. Interpretation Manual of European Union Habitats - EUR28. European Commission, DG Environment, p. 144 Nature ENV B.3.

Fesenmyer, K.A., Dauwalter, D.C., Evans, C., Allai, T., 2018. Livestock management, beaver, and climate influences on riparian vegetation in a semiarid landscape. PLoS One 13, e0208928. https://doi.org/10.1371/journal.pone.0208928.

Fu, B., Burgher, I., 2015. Riparian vegetation NDVI dynamics and its relationship with climate, surface water and groundwater. J. Arid Environ. 113, 59-68. https://doi.org/ 10.1016/JJARIDENV.2014.09.010.

Fu, Y.H., Piao, S., Op de Beeck, M., Cong, N., Zhao, H., Zhang, Y., Menzel, A., Janssens, I.A 2014. Recent spring phenology shifts in western Central Europe based on multiscale observations. Glob. Ecol. Biogeogr. 23, 1255-1263. https://doi.org/10.1111/ geb.12210.

Garssen, A.G., Verhoeven, J.T.A., Soons, M.B., 2014. Effects of climate-induced increases in summer drought on riparian plant species: a meta-analysis. Freshw. Biol. 59, 1052-1063. https://doi.org/10.1111/fwb.12328.

Gobron, N., Pinty, B., Mélin, F., Taberner, M., Verstraete, M.M., Belward, A., Lavergne, T. Widlowski, J.L., 2005. The state of vegetation in Europe following the 2003 drought. Int. J. Remote Sens. 26, 2013-2020. https://doi.org/10.1080/01431160412331330293.

Goetz, S.J., 2006. Remote sensing of riparian buffers: past Progress and future prospects. J. Am. Water Resour. Assoc. 42, 133-143. https://doi.org/10.1111/j.1752-1688.2006. tb03829.x.

Gómez-Gener, L., Lupon, L., Laudon, H., Sponseller, R.A., 2020. Drought alters the biogeochemistry of boreal stream networks. Nat. Commun. 11, 1795. https://doi.org/ 10.1038/s41467-020-15496-2.

Gordo, O., Sanz, J.J., 2010. Impact of climate change on plant phenology in Mediterranean ecosystems. Glob. Chang. Biol. 16, 1082-1106. https://doi.org/10.1111/j.13652486.2009.02084.X.

Gouveia, C.M., Trigo, R.M., Beguería, S., Vicente-Serrano, S.M., 2017. Drought impacts on vegetation activity in the Mediterranean region: an assessment using remote sensing data and multi-scale drought indicators. Glob. Planet. Chang. 151, 15-27. https://doi. org/10.1016/j.gloplacha.2016.06.011.

Huntington, J., McGwire, K., Morton, C., Snyder, K., Peterson, S., Erickson, T., Niswonger, R. Carroll, R., Smith, G., Allen, R., 2016. Assessing the role of climate and resource management on groundwater dependent ecosystem changes in arid environments with the Landsat archive. Remote Sens. Environ. 185, 186-197. https://doi.org/10.1016/j. rse.2016.07.004

IPCC, 2014. In: Edenhofer, O., Pichs-Madruga, R., Sokona, Y., Farahani, E., Kadner, S., Seyboth, K., Adler, A., Baum, I., Brunner, S., Eickemeier, P., Kriemann, B., Savolainen, J., Schlömer, S., von Stechow, C., Zwickel, T., Minx, J.C. (Eds.), Climate Change 2014: Mitigation of Climate Change. Contribution of Working Group III to the Fifth Assessment Report of the Intergovernmental Panel on Climate Change. Cambridge University Press, Cambridge, United Kingdom and New York, NY, USA.

Johansen, K., Phinn, S., Dixon, I., Douglas, M., Lowry, J., 2007. Comparison of image and rapid field assessments of riparian zone condition in Australian tropical savannas. For. Ecol. Manag. 240, 42-60. https://doi.org/10.1016/j.foreco.2006.12.01531.

Johnson, T.E., Butcher, J.B., Parker, A., Weaver, C.P., 2012. Investigating the sensitivity of U.S. streamflow and water quality to climate change: U.S. EPA Global Change Research Program's 20 Watersheds Project. J. Water Resour. Plan. Manag. 138, 453-464. https://doi.org/10.1061/(ASCE)WR.1943-5452.0000175.

Klemas, V., 2014. Remote sensing of riparian and wetland buffers: an overview. J. Coast. Res. 30, 869-880. https://doi.org/10.2112/JCOASTRES-D-14-00013.1.

Kominoski, J.S., Rosemond, A.D., 2012. Conservation from the bottom up: forecasting effects of global change on dynamics of organic matter and management needs for river networks. Freshwater Science 31, 51-68. https://doi.org/10.1899/10-160.1.

Lamberti, G.A., Entrekin, S.A., Griffith, N.A., Tiegs, S.D., 2017. Coarse particulate organic matter: storage, transport, and retention. In: Hauer, F.R., Lamberti, G. (Eds.), Methods in Stream Ecology 2017. Elsevier. ISBN: 978-0-12-416558-8 https://doi.org/10.1016/ B978-0-12-813047-6.00004-8.

Larsen, S., Muehlbauer, J.D., Marti, E., 2015. Resource subsidies between stream and terrestrial ecosystems under global change. Global change ecology 22, 2489-2504. https://doi.org/10.1111/gcb.13182.

Ledesma, J.L.J., Kothawala, D.N., Bastviken, P., Maehder, S., Grabs, T., Futter, M.N., 2018 Stream dissolved organic matter composition reflects the riparian zone, not upslope soils in boreal forest headwaters. Water Resour. Res. 54, 3896-3912. https://doi.org/ 10.1029/2017WR021793.

Leuzinger, S., Zotz, G., Asshoff, R., Körner, C., 2005. Responses of deciduous forest trees to severe drought in Central Europe. Tree Physiol. 25, 641-650. https://doi.org/10.1093/ treephys/25.6.641. 
Li, J., Roy, D.P., 2017. A global analysis of Sentinel-2A, Sentinel-2B and Landsat-8 data revisit intervals and implications for terrestrial monitoring. Remote Sens. 9, 902. https://doi.org/10.3390/rs9090902.

Lloret, F., Lobo, A., Estevan, H., Maisongrande, P., Vayreda, J., Terradas, J., 2007. Woody plant richness and NDVI response to drought events in Catalonian (northeastern Spain) fores. Ecology 88, 2270-2279. https://doi.org/10.1890/06-1195.1.

Lloret, F., de la Riva, E.G., Pérez-Ramos, I.M., Marañón, T., Saura-Mas, S., Díaz-Delgado, R., Villar, R., 2016. Climatic events inducing die-off in Mediterranean shrublands: are species' responses related to their functional traits? Oecologia 180, 961-973. https://doi.org/10.1007/s00442-016-3550-4.

Lobo, A., Maisongrande, P., 2005. Stratified analysis of satellite imagery of SW Europe during summer 2003: the differential response of vegetation classes to increased water deficit. Hydrol. Earth Syst. Sci. Discuss. 2, 2025-2060. https://doi.org/10.5194/ hessd-2-2025-2005.

Masante, D., Barbosa, P., McCormick, N., 2018. Drought in central-northern Europe. Report of the Copernicus European Drought Observatory (EDO) and Emergency Response Coordination Centre (ERCC) Analytical Team. Available for download at EDO website: https://edo.jrc.ec.europa.eu/gdo/php/index.php?id=2050. (Accessed 10 December 2020).

20th century Portuguese climate and climate scenarios. In: Miranda, P.M.A., Coelho, F.E.S., Tomé, A.R., Valente, M.A., Carvalho, A., Pires, C., Pires, H.O., Pires, V.C., Ramalho, C., Santos, F.D., Forbes, K., Moita, R. (Eds.), 2002, Climate Change in Portugal: Scenarios, Impacts and Adaptation Measures (SIAM Project), 23-83, Gradiva (454 pp.).

Mzobe, P., Berggren, M., Pilesjö, P., Lundin, E., Olefeldt, D., Roulet, N.T., Persson, A., 2018. Dissolved organic carbon in streams within a subarctic catchment analysed using a GIS/remote sensing approach. PLoS One 13, e0199608. https://doi.org/10.1371/journal.pone.0199608.

Naiman, R.J., Decamps, H., 1997. The ecology of interfaces: riparian zones. Annu. Rev. Ecol. Syst. 28, 621-658. https://doi.org/10.1146/annurev.ecolsys.28.1.621.

Naiman, R.J., Decamps, H., Mcclain, M.E., 2005. Riparia: Ecology, Conservation, and Management of Streamside Communities. Elsevier Academic Press, London 0-12663315-0 https://doi.org/10.1002/aqc.777.

Nakagawa, S., Schielzeth, H., 2013. A general and simple method for obtaining R2 from generalized linear mixed-effects models. Methods Ecol. Evol. 4, 133-142. https:// doi.org/10.1111/j.2041-210x.2012.00261.x.

Novillo, C.J., Arrogante-Funes, P., Romero-Calcerrada, R., 2019. Recent NDVI trends in mainland Spain: land-cover and phytoclimatic-type implications. ISPRS Int. J. GeoInf. 8, 43. https://doi.org/10.3390/ijgi8010043.

Nunes, L.J.R., Meireles, C.I.R., Gomes, C.J.P., Almeida Ribeiro, N.M.C., 2019. The evolution of climate changes in Portugal: determination of trend series and its impact on forest development. Climate 7, 78. https://doi.org/10.3390/cli7060078.

Ono, E.R., Manoel, P.S., Melo, A.L.U., Uieda, V.S., 2020. Effects of riparian vegetation removal on the functional feeding group structure of benthic macroinvertebrate assemblages. Community Ecology 21, 145-157. https://doi.org/10.1007/s42974-02000014-7.

Peng, J., Liu, Z., Liu, Y., Wu, J., Han, Y., 2012. Trend analysis of vegetation dynamics in Qinghai-Tibet Plateau using Hurst Exponent. Ecol. Indic. 14, 28-39. https://doi.org/ 10.1016/J.ECOLIND.2011.08.011.

Piedelobo, L., Taramelli, A., Schiavan, E., Valentini, E., Molina, J., Xuan, A.N., GonzálezAguilera, D., 2019. Assessment of green infrastructure in riparian zones using Copernicus programme. Remote Sens. 11, 2967. https://doi.org/10.3390/rs11242967.

Portal do Clima. ClimateClimate Change in Portugal. IPMA. Instituto Português do Mar e da Atmosfera. Lisboa. Available at: http://portaldoclima.pt/en/. (accessed December 10, 2020).

QGIS Development Team, 2009. QGIS Geographic Information System. Open Source Geospatial Foundation Available at:. http://qgis.org. (Accessed 10 December 2020).

Rajah P. Odindi, J. Mutanga O, Kiala Z , 2019. The utility of Sentinel-2 Vegetation Indices (VIs) and Sentinel-1 Synthetic Aperture Radar (SAR) for invasive alien species detection and mapping. Nature Conservation 35, 41-61. https://doi.org/10.3897/ natureconservation.35.29588.

Raymondi R.R., Cuhaciyan J.E., Glick P., Capalbo S.M., Houston L.L., Shafer S.L., Grah O. (2013). Water resources, in Dalton M.M., Mote P.W., Snover A.K.(eds.) 2013. Climate Change in the Northwest: Implications for Our Landscapes, Waters, and Communities. Island Press, Washington, DC, pp:41-66.

Renöfält, B.M., Nilsson, C., Jansson, R., 2005. Spatial and temporal patterns of species richness in a riparian landscape. J. Biogeogr. 32, 2025-2037. https://doi.org/10.1111/ j.1365-2699.2005.01328.x.

Rivas-Martínez, S., Penas, A., Díaz González, T.E., Cantó, P., del Río, S., Costa, J.C., Herrero, L., Molero, J., 2017. Biogeographic units of the iberian peninsula and baelaric islands to district level. A concise synopsis. In: Loidi J. (eds) The Vegetation of the Iberian Peninsula. Plant and Vegetation, vol. 12Springer, Cham https://doi.org/10.1007/978-3319-54784-8_5.

Rocchini, D., Balkenhol, N., Carter, G.A., Foody, G.M., Gillespie, T.W., He, K.S., Kark, S., Levin, N., Lucas, K., Luoto, M., Nagendra, H., Oldeland, J., Ricotta, C., Southworth, J., Neteler, M., 2010. Remotely sensed spectral heterogeneity as a proxy of species diversity: recent advances and open challenges. Eco. Inform. 5, 318-329. https://doi.org/ 10.1016/j.ecoinf.2010.06.001.

Rocchini, D., Boyd, D.S., Féret, J.B., Foody, G.M., He, K.S., Lausch, A., Nagendra, H., Wegmann, M., Pettorelli, N., 2016. Satellite remote sensing to monitor species di versity: potential and pitfalls. Remote Sens. Ecol. Conserv. 2, 25-36. https://doi.org/ 10.1002/rse2.9

Rocchini, D., Luque, S., Pettorelli, N., Bastin, L., Doktor, D., Faedi, N., Feilhauer, H., Féret, J.B., Foody, G.M., Gavish, Y., Godinho, S., Kunin, W.E., Lausch, A., Leitao, P.J., Marcantonio, M., Neteler, M., Ricotta, C., Schmidtlein, S., Vihervaara, P., Wegmann, M., Nagendra, H., 2018. Measuring $\beta$-diversity by remote sensing: a challenge for biodiversity monitoring. Methods Ecol. Evol. 9, 1787-1798. https://doi.org/10.1111/ 2041-210X.12941.

Schmidtlein, S., Fassnacht, F.E., 2017. The spectral variability hypothesis does not hold across landscapes. Remote Sens. Environ. 192, 114-125. https://doi.org/10.1016/j. rse.2017.01.036.

Senf, C., Buras, A., Zang, C., Rammig, A., Seidl, R., 2020. Excess forest mortality is consistently linked to drought across Europe. Nat. Commun. 11, 6200. https://doi.org/ 10.1038/s41467-020-19924-1.

Stella, J.C., Bendix, J., 2019. Chapter 5 - multiple stressors in riparian ecosystems. In: Elosegi, A., Ludwig, R. (Eds.), Sabater S. Elsevier, Multiple Stressors in River Ecosystems. ISBN: 9780128118009 , pp. 81-110 https://doi.org/10.1016/B978-0-12811713-2.00005-4.

Stella, J.C., Rodríguez-González, P.M., Dufour, S., Bendix, J., 2013. Riparian vegetation research in Mediterranean-climate regions: common patterns, ecological processes, and considerations for management. Hydrobiologia 719, 291-315. https://doi.org/ 10.1007/s10750-012-1304-9.

Stöckli, R., Vidale, P.L., 2004. European plant phenology and climate as seen in a 20-year AVHRR land-surface parameter dataset. Int. J. Remote Sens. 25, 3303-3330. https:// doi.org/10.1080/01431160310001618149.

Stromberg, J., McCluney, K.E., Dixon, M.D., Meixner, T., 2013. Dryland riparian ecosystems in the American southwest: sensitivity and resilience to climatic extremes. Ecosystems 16, 411-415. https://doi.org/10.1007/s10021-012-9606-3.

Sudmanns, M., Tiede, D., Augustin, H., Lang, S., 2019. Assessing global Sentinel-2 coverage dynamics and data availability for operational Earth observation (EO) applications using the EO-Compass. International Journal of Digital Earth 13, 768-784. https:// doi.org/10.1080/17538947.2019.1572799.

Sun, Y., Wang, C., Chen, H.Y.H., Ruan, H., 2020. Response of plants to water stress: a metaanalysis. Front. Plant Sci. 11, 978. https://doi.org/10.3389/fpls.2020.00978.

Swanson, S., Kozlowski, D., Hall, R., Heggem, D., Lin, J., 2017. Riparian proper functioning condition assessment to improve watershed management for water quality. J. Soil Water Conserv. 72, 168-182. https://doi.org/10.2489/jswc.72.2.168.

Tomsett, C., Leyland, J., 2019. Remote sensing of river corridors: a review of current trends and future directions. River Res Applic. 35, 779-803. https://doi.org/10.1002/ rra.3479.

Torresani, M., Rocchini, D., Sonnenschein, R., Zebisch, M., Marcantonio, M., Ricotta, C. Tonon, G., 2019. Estimating tree species diversity from space in an alpine conifer forest: the Rao's Q diversity index meets the spectral variation hypothesis. Ecological Informatics 52, 26-34. https://doi.org/10.1016/j.ecoinf.2019.04.001.

Trigo, R., Da Camara, C.C., 2000. Circulation weather types and their influence on the precipitation regime in Portugal. Int. J. Climatol. 20, 1559-1581. https://doi.org/10.1002/ 1097-0088(20001115)20:13<1559::AID-JOC555>3.0.CO;2-5.

Vieira, J.M.P., Pinho, J.L.S., Duarte, A.A.L.S., 1998. Eutrophication vulnerability analysis: a case study. Water Sci. Technol. 37, 121-128. https://doi.org/10.1016/S0273-1223 (98)00063-8.

Wang, J., Rich, P.M., Pricek, P., 2003. Temporal responses of NDVI to precipitation and temperature in the central Great Plains, USA. Int J Remote sensing 4, 2345-2364. https://doi.org/10.1080/01431160210154812.

Wang, R., Gamon, J.A., Montgomery, R.A., Townsend, P.A., Zygielbaum, A.I., Bitan, K., Tilman, D., Cavender-Bares, J., 2016. Seasonal variation in the NDVI-species richness relationship in a prairie grassland experiment (Cedar Creek). Remote Sens. 8, 128. https://doi.org/10.3390/rs8020128.

Wang, C., Fu, B., Zhang, L., Xu, Z., 2019. Soil moisture-plant interactions: an ecohydrological review. J. Soils Sediments 19, 1-9. https://doi.org/10.1007/s11368018-2167-0.

Warren, D.R., Keeton, W.S., Kiffney, P.M., Kaylor, M.J., Bechtold, H.A., Magee, J., 2016. Changing forests-changing streams: riparian forest stand development and ecosystem function in temperate headwaters. Ecosphere 7, e01435. https://doi.org/ $10.1002 /$ ecs2.1435.

Wood, S.N., 2017. Generalized Additive Models: An Introduction With R. 2nd edition. Chapman \& Hall/CRC, New York (NY) https://doi.org/10.1201/9781315370279.

Zuur, A.F., Ieno, E.N., Walker, N.J., Saveliev, A.A., Smith, G.M., 2009. Mixed Effects Models and Extensions in Ecology With R. Springer, New York (NY) 978-0-387-87457-9 https://doi.org/10.1007/978-0-387-87458-6. 